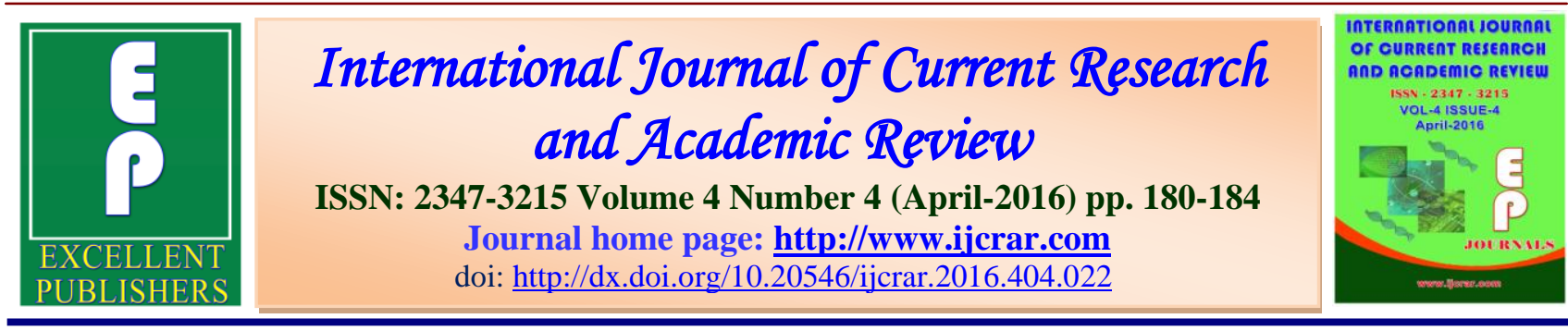

\title{
Estimation of Serum Ferritin - An Index of Preclinical Iron Deficiency State in Voluntary Male Blood Donors - A Cross-Sectional Study
}

\author{
B. Sujatha* and I.J. V. Pradeep Vaiz \\ Department of Physiology, Tirunelveli Medical College, Tirunelveli, India \\ *Corresponding author
}

\begin{tabular}{|l|l|}
\hline \multirow{2}{*}{$\begin{array}{l}\text { KEYWORDS } \\
\text { donors, donation } \\
\text { frequency, serum } \\
\text { ferritin, hemoglobin, } \\
\text { iron deficiency. }\end{array}$} & $\begin{array}{l}\text { A B S T R A C T } \\
\text { medical fraternity. But, the donor safety after blood donation is yet to be } \\
\text { answered with detailed studies. So, we planned for a study of body iron stores } \\
\text { in voluntary male blood donors based on their frequency of donation and total } \\
\text { life time donation. 72 study subjects were divided into four groups based on } \\
\text { their frequency of donations. Serum ferritin level was estimated using } \\
\text { quantitative turbidimetric method with semi-automated analyzer and } \\
\text { difference was compared among the groups. P value <0.05 was considered to } \\
\text { be statistically significant. It showed a considerable decrease in mean ferritin } \\
\text { values of those voluntary blood donors who had an increase in frequency of } \\
\text { blood donation. To conclude, the aim of our health services should not be in } \\
\text { reaching the desired target rather, it should increase the voluntary donor pool } \\
\text { to meet the demands. This could provide a healthy voluntary blood donor } \\
\text { pool in our society. }\end{array}$ \\
\hline
\end{tabular}

\section{Introduction}

"Give blood - Give life", "Give freely, Give often, Blood donation matters" is the motto and slogan of World health organization in the year 2015. Blood donation is often thought in a one way sense by which it serves the purpose of the situation. Blood safety more often concentrates the recipient part of it rather than the donor part. It is not only important to give a safe blood to the recipient but also it is important to note that the donor is safe after donation.
Blood donation should always be volunteered. It is very important for the part of our National Health system to be sure that it maintains or increases the voluntary donor pool. So it is necessary that every voluntary donor knows the frequency interval for blood donation.

India caters a population of over 1.2 billion. The total annual blood units required to meet the demands of major surgeries, road traffic accidents, acute emergencies, 
obstetric emergencies, neonatal emergencies and for the transfusion of hemolytic anemia is estimated around 12 million. But, the blood store we have in our government and private sector is only around 9 million. So, in order to meet this additional requirement we plan and conduct several voluntary blood donation camps. But very often the donors are from the existing pool of voluntary blood donors. So these repeated voluntary blood donations can cause an effect on their hemoglobin and iron store levels. This study focuses on the impact of frequency of blood donation and total life time donation on body iron stores.

The main aim and objectives of this study includes, to estimate serum ferritin levels in voluntary male blood donors. And also to correlate them with the frequency of blood donation and total lifetime donation.

\section{Materials and Methods}

This study was conducted in the Department of Transfusion medicine, Tirunelveli medical college after obtaining the institutional ethical committee approval. It was a cross-sectional study. The sample size was 72 which included voluntary male donors between the ages of 18-35 years. They were screened as per norms of blood donation screening camps.

Screening included measurement of weight, general examination for jaundice, lymphadenopathy, anemia, edema, pulse rate, temperature, blood pressure, clinical examination of respiratory system, clinical examination of cardiovascular system, clinical examination of abdomen and nervous system. Female voluntary blood donors were excluded as they accounted for less than $3 \%$ of voluntary blood donors' statistical records. Written informed consent was obtained from the individuals prior to the donation.

\section{Inclusion Criteria}

Voluntary male blood donors who were fit after screening.

Age groups between 18-35 years

\section{Exclusion Criteria}

Voluntary male donors who were rejected in screening

Donors with anemia (Hemoglobin<12.5 gm $\%)$

Donors with systemic illnesses like Diabetes \& hypertension

Female blood donors

Male blood donors above 35 years and below 18 years

Donors unwilling to participate in the study

Pre-donation hemoglobin was estimated using electronic cell counter method. Hemoglobin was measured in grams per decilitre. Serum ferritin was estimated by quantitative turbidimetric method using semi-automated analyzer. Serum ferritin was estimated in micrograms per litre. Normal ferritin values had a wide range from 20200 micrograms per litre.

\section{Statistical Analysis}

Statistical analysis was done using SPSS software version 11. Mean, SD \& difference between groups were obtained. Independent sample t-test was used for analysis

\section{Results and Discussion}

Group I was compared with other three groups. All the other groups showed a significant decrease in ferritin values $(p<0.05)$. Table 3 compares group II with group III \& IV. It showed a significant decrease in ferritin values $(\mathrm{p}<0.05)$ in group III, whereas, there was no significant difference for group IV. Table 4 compares group III \& group IV. Group IV showed a 
significant $\mathrm{p}$ value when compared with group III, but the values were greater than group III.

Iron in our body has many vital functions. Moreover, iron is a one-way substance i.e. it is absorbed when required and only minimally excreted in stool with nil excretion in urine and bile. Only $10 \%$ of the ingested non-heme iron is absorbed. Total body iron is 3-5 grams, out of which 60$70 \%$ is within hemoglobin in the red blood cell. One unit of blood bled has 230-250 milligrams of iron (Nils Milman et al., 1984; Romilla Mittal et al., 2006) which is around $8-10 \%$ of that present in red blood cell. So, blood donation literally loses iron in a significant quantity which will be replenished in a normal adult within 12-16 weeks (Romilla Mittal et al., 2006).

Table.1 Categorization of Groups based on Frequency of Blood Donation \& Lifetime Blood Donation

\begin{tabular}{|c|c|c|c|}
\hline $\begin{array}{l}\text { Group } \\
\mathbf{n}=\text { no. of voluntary } \\
\text { donors in the group }\end{array}$ & $\begin{array}{c}\text { Total No. of previous } \\
\text { blood donation within } \\
\text { the year }\end{array}$ & $\begin{array}{c}\text { Previous donation } \\
\text { interval }\end{array}$ & Total life time donation \\
\hline I $\quad \mathbf{n = 2 3}$ & 0 ( first donation ) & - & 0 \\
\hline II $\quad \mathbf{n = 2 0}$ & 1 & $>6$ months & - \\
\hline III $\quad \mathbf{n = 1 4}$ & 2 & $<6$ months & $>5$ \\
\hline IV $\quad \mathbf{n = 1 5}$ & - & $>6$ months & - \\
\hline
\end{tabular}

Table.2 Intergroup Comparison of Hemoglobin and Serum Ferritin Values

\begin{tabular}{|c|c|c|c|c|c|c|c|c|c|c|c|}
\hline & \multicolumn{3}{|c|}{ GROUP I } & \multicolumn{3}{c|}{ GROUP II } & \multicolumn{3}{c|}{ GROUP II } & \multicolumn{3}{c|}{ GROUP IV } \\
\hline & Mean & SD & Mean & SD & P value & Mean & SD & P value & Mean & SD & P value \\
\hline $\mathrm{Hb}$ & 13.88 & 0.98 & 13.32 & 0.6 & 0.029 & 13.04 & 0.42 & 0.001 & 13.53 & 0.59 & 0.181 \\
\hline Ferritin & 110.14 & 34.91 & 70.3 & 27.05 & $<\mathbf{0 . 0 0 0 1}$ & 34.68 & 15.54 & $<\mathbf{0 . 0 0 0 1}$ & 69.37 & 27.15 & $<\mathbf{0 . 0 0 0 1}$ \\
\hline
\end{tabular}

$P$ value $<0.05$ is significant

Table.3 Comparison of Group II with Group III \& IV

\begin{tabular}{|c|c|c|c|c|c|c|c|c|}
\hline & \multicolumn{2}{|c|}{ GROUP II } & \multicolumn{3}{|c|}{ GROUP III } & \multicolumn{3}{c|}{ GROUP IV } \\
\hline & Mean & SD & Mean & SD & P value & Mean & SD & P value \\
\hline $\mathrm{Hb}$ & 13.32 & 0.6 & 13.04 & 0.42 & 0.121 & 13.53 & 0.59 & 0.317 \\
\hline Ferritin & 70.3 & 27.05 & 34.68 & 15.54 & $<\mathbf{0 . 0 0 0 1}$ & 69.37 & 27.15 & 0.921 \\
\hline
\end{tabular}

$\mathrm{P}$ value $<0.05$ is significant

Table.4 Comparison of Group III and Group IV

\begin{tabular}{|c|c|c|c|c|c|}
\hline & \multicolumn{2}{|c|}{ GROUP III } & \multicolumn{3}{c|}{ GROUP IV } \\
\hline & Mean & SD & Mean & SD & P value \\
\hline $\mathrm{Hb}$ & 13.04 & 0.42 & 13.53 & 0.59 & 0.017 \\
\hline Ferritin & 34.68 & 15.54 & 69.37 & 27.15 & $<\mathbf{0 . 0 0 0 1}$ \\
\hline
\end{tabular}

$P$ value $<0.05$ is significant 
Figure.1 Pie Chart Representing the Distribution of Subjects

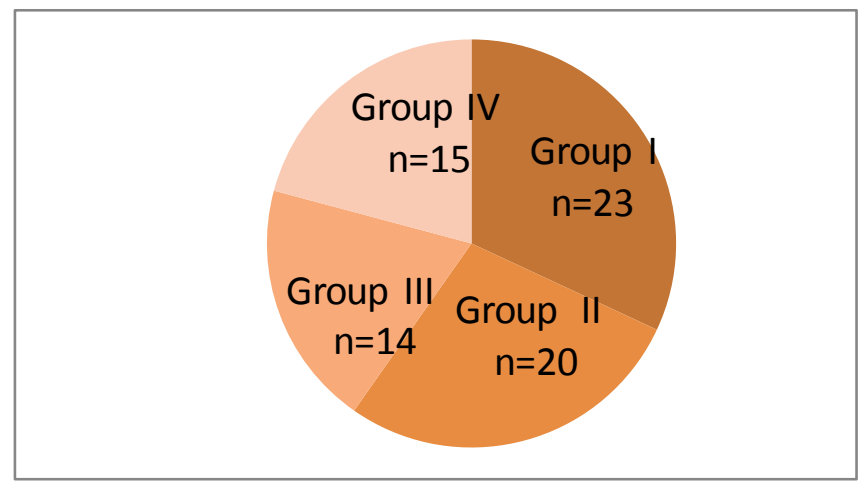

Studies done by (Nils Milman et al., 1984; Gunnar Biregard et al., 1978; Norashikin et al., 2006; Romilla Mittal et al., 2006) have proved serum ferritin to be a sensitive tool for estimation of iron stores in our body. Nowadays ferritin has been used as a marker of inflammation. But, in normal individuals it reflects the iron stores. Serum ferritin ranges in micrograms in our body with a broader range for males than females.

In the study by Milman et al. (2006) the study population was large and they have categorized the ferritin levels as decreased and depleted. Study done by Norashikin et al. (2006) took into consideration a period of two years for assessing the frequency of donation, whereas, in our study the groups were categorized using one year for the frequency of blood donation. First time voluntary blood donors had a mean serum ferritin values higher than those of repeated donors (Romilla Mittal et al., 2006).

The studies (Nils Milman et al., 1984; Gunnar Biregard et al., 1978; Norashikin et al., 2006; Romilla Mittal et al., 2006) also showed a decrease in ferritin values when the frequency of blood donation was increased which was consistent with our study.

\section{Conclusion}

In our study, it is very obvious that serum ferritin decreases with increase in life time donation. But still, when the frequency of blood donation is decreased, the serum ferritin values tend to be closer to the control group. Consequently, when the total life time donation and the frequency of donation are increased there is a considerable fall in the serum ferritin values. It can be concluded that information, education \& counselling of the existing voluntary blood donor pool is very important in maintaining the reserve of safe blood for the future. Moreover sensitization of the new voluntary donors improves the quality of blood donation safety programs.

\section{References}

Akarsu, S., Kilic, M., Yilmaz, E., Aydin, M., Taskin, E., Aygun, A.D. 2006. Frequency of hypoferritinemia, iron deficiency and iron deficiency anemia in outpatients. Acta Haematol, 116: 46-50.

Alvarez-Ossorio, L., Kirchner, H., Kluter, H., Schlenke, P. 2000. Low ferritin levels indicate the need for iron supplementation: strategy to minimize iron-depletion in regular blood donors. 
Transfus. Med., 10: 107-12.

Boulton, F., Collis, D., Inskip, H., Paes, H., Garlick, M. 2000. A study of the iron and HFE status of blood donors, including a group who failed the initial screening for anemia. $B r . \quad J$. Haematol., 108: 434-9.

Fielding, J., Carabus, C., Brunstrom, G.M. 1968. Storage iron depletion in male blood donors. J. Clin. Pathol., 2: 402405.

Green, R., Charlton, R., Seftel, H., et al. 1968. Body iron excretion in man- a collaborative study. Am. J. Med., 45: 336-53.

Gunnar Birgegard, Claes Hogman, et al. 1978. Serum ferritin levels in male blood donors. Vox Sang., 34: 65-70.

Haskins, D., Stevens Finch, S., Finch, C. 1952. Iron metabolism- iron stores in man as measured by phlebotomy. $J$. Clin. Invest., 31: 543-547.

Nadarajah, V.S., Eow, G. 2002. Anemia and iron among blood donors in blood transfusion unit in Malaysia. Malaysian J. Pathol., 24: 99-102.

Nils Milman, Sondergaard. 1984. Iron stores in male blood donors evaluated by serum ferritin. Transfusion, 24: 464468.

Norashikin, T.M., Roshan, et al. 2006. A study of serum ferritin levels among male blood donors in hospital university sans Malaysia, Vol.37 No.2.

Romilla Mittal, Neelam Marwaha, et al. 2006. Evaluation of iron stores in blood donors by serum ferritin. Indian J. Med. Res., 124: pp 641-646.

Simon, T.L. 2002. Iron, iron everywhere but not enough to donate. Transfusion, 42: 664-5.

Simon, T.L., Garry, P.J., Hooper, E.M. 1981. Iron stores in blood donors. $J$. Am. Med. Assoc., 245: 2038-2043.

Walters, G.O., Miller, F.M., Worwood, M. 1973. Serum ferritin concentrations and iron stores in normal subjects. $J$. Clin. Pathol., 26: 770-2.

\section{How to cite this article:}

Sujatha, B., and I.J. V. Pradeep Vaiz. 2016. Estimation of Serum Ferritin - An Index of Preclinical Iron Deficiency State in Voluntary Male Blood Donors - A Cross-Sectional Study. Int.J.Curr.Res.Aca.Rev.4(4): 180-184. doi: http://dx.doi.org/10.20546/ijcrar.2016.404.022 